\title{
A Rare Cause of Healthcare-associated Infection in a Pediatric Infectious Diseases Unit
}

\author{
Bir Çocuk Enfeksiyon Hastalıkları Biriminde Sağllk Hizmeti İlş̧kili \\ Enfeksiyonun Nadir Bir Nedeni
}

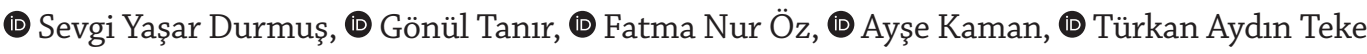 \\ Dr. Sami Ulus Maternity and Children's Research and Training Hospital, Clinic of Pediatric Infectious Diseases, \\ Ankara, Turkey
}

Cite this article as: Durmuş SY, Tanır G, Öz FN, Kaman A, Aydın Teke T. A Rare Cause of Healthcare-associated Infection in a Pediatric Infectious Diseases Unit. Turkiye Parazitol Derg 2020;44(2):122-3.

\section{Dear Editor,}

Head lice infestation (pediculosis capitis) is one of the common but ignored puplic health problem. It is a disease usually associated only with a lack of basic hygiene, low socio-economic status and crowded living conditions. It usually seems among preschool and elementary school children. However nosocomial epidemic outbreaks of head lice were reported. In a systematic review from Turkey, head lice prevalence was in a wide range as $0.3-34.1 \%$ (1-3). Here we present a nosocomial head lice infestation among doctors in a pediatric infectious disease unit.

Case 1 was working as a pediatric resident in pediatric infectious disease unit on June 2018. She felt pruritus on her head, two weeks after starting to work. When she was brushing her hair, she saw an insect on her comb and noticed a living lice. The day after, Case 1 warned her coworker because of being infested with head lice. Thus Case 2 was examined by Case 1 and unhatched nits were found on her hair. When Case 2 learned her diagnosis, she examined her boy friend (Case 3) and unhatced nits were found on his hair too. All three cases were successfully treated with permethrin. Three days after, the index case was revealed. The index case had been hospitalized in pediatric infectious disaese unit because of dental abscess. Patient and her roommates were treated with permethrin.

Head lice transmits by direct contact with head of an infested person or using same personal belongings
$(2,4)$. It has been reported that, health care-associated transmission of pediculosis is possible, the direct or indirect contact like head-to-head contact or sharing of combs are necessary to spread this infection, however, it is less likely in medical settings than at home (5). Our residents contacted with patiens head when they were putting intravenous line on her arm and they were using the same pillow in the night shifts.

First choise of treatment of head lice is permethrin $1 \%$ (1-3). Adapting standart precautions is an important way for prevention of health caregivers, especially in pediatric hospitals. Head lice should be kept in mind as a healthcare-associated infestation. If the disease had not been recognized and treated, outbreak would have occured among health caregivers and patients.

\section{* Ethcis}

Peer-review: Internally peer-reviewed.

\section{Authorship Contributions}

Surgical and Medical Practices: S.Y.D., G.T., T.A.T., Concept: F.N.Ö., T.A.T., Design: G.T., F.N.Ö., A.K., Data Collection or Processing: S.Y.D., F.N.Ö., A.K., Analysis or Interpretation: G.T., F.N.Ö., T.A.T., Literature Search: S.Y.D., A.K., Writing: S.Y.D., G.T., T.A.T.

Conflict of Interest: No conflict of interest was declared by the authors.

Financial Disclosure: The authors declared that this study received no financial support. 


\section{REFERENCES}

1. Özkan Ö, Hamzaoğlu O, Yavuz M. The Prevalence and Management of Pediculosis Capitis in Turkey: A Systematic Review. Turkiye Parazitol Derg 2015;39:35-46.

2. Frankowski BL, Bocchini JA Jr. Council on School Health and Committee on Infectious Diseases. Head lice. Pediatrics 2010;126:392-403.

3. Soleimani-Ahmadi M, Jaberhashemi SA, Zare M, Sanei-Dehkordi A. Prevalence of head lice infestation and pediculicidal effect of permethrine shampoo in primary school girls in a low-income area in southeast of Iran. BMC Dermatol 2017;17:10.

4. Meister L, Ochsendorf F. Head Lice. Dtsch Arztebl Int 2016;113:763-72.

5. Huskins WC, Sammons JS, Coffin SE. Health Care-Associated Infections. Cherry JD, Demmler-Harrison GJ, Kaplan SL, Steinbach WJ, Hotez PJ editors. Feigin and Cherry's Textbook of Pediatric Infectious Diseases. Philadelphia: Elsevier; 2019.p.2514-42. 